\title{
A History of the Process of Capital Accumulation in Pittsburgh: A Marxist Interpretation-Part III
}

\author{
David Houston* \\ 1950-1980 THE DECLINE AND RESTRUCTURING OF THE \\ ACCUMULATION PROCESS
}

After World War II all of the latent tendencies in the Pittsburgh economy became manifest and relative decline became absolute. The shrinking of the base of accumulation made necessary a shift from an emphasis on the production process in the region to the circulation process with recognition of the increasingly international aspects in the accumulation process. An attempt was made to create Pittsburgh as a center for the international management of capital. Corporate headquarters with all of their attendant functions and finance capital were to be the new representations of the international accumulation process. Called a "Renaissance", it was in fact an attempt by one of the richest and hence most powerful capitalist families in the United States, the Mellons, to restructure the regional economy to permit the continued appropriation of surplus value. However, under the new scheme surplus value would not be produced primarily in the region but rather in every corner of the world, while its circulation, its direction, its development would be managed from the corporate towers of the Golden Triangle.

The Mellon family and fortune were particularly well suited to this task. By the beginning of the 20th century Mellon capital was dominant in the region and was perceived as such. Further the Mellons as finance capitalists had for the most part maintained a banker's arms length from the production aspects of accumulation. Corporate shares, bonds, mortgages, loans, and reorganization were the stuff of which the family billions were made. Hence it was in the nonproductive realms of accumulation that they saw both their past and their future. Taking advantage of the conditions of accumulation was a Mellon trademark, and if Pittsburgh was declining as a manufacturing center, then

\footnotetext{
*Professor of Economics, University of Pittsburgh, Pittsburgh, PA.
}

†EDITOR'S NOTE: This is the concluding portion of Professor Houston's paper interpreting the process of capital accumulation in Pittsburgh. Part I was published in Volume 9, No. 1 and Part II in Volume 9, No. 3 of this journal. In this final portion of the paper, Professor Houston brings his analysis up-to-date, examining the period 1950-1980. 
TABLE 18

\section{Absolute and Relative Growth in Pittsburgh \\ SMSA and its Components 1950-1980}

\begin{tabular}{c|c|c|c|c|c|c}
\hline & $\begin{array}{c}\text { City of } \\
\text { Pittsburgh } \\
(000)\end{array}$ & $\begin{array}{c}\text { Rest of } \\
\text { Allegheny } \\
\text { County } \\
(000)\end{array}$ & $\begin{array}{c}\text { Allegheny } \\
\text { County } \\
(000)\end{array}$ & $\begin{array}{c}\text { Beaver } \\
\text { Washington } \\
\text { Westmoreland } \\
(000)\end{array}$ & $\begin{array}{c}\text { SMSA } \\
(000)\end{array}$ & $\begin{array}{c}\text { U.S. } \\
(000,000)\end{array}$ \\
\hline 1950 & 677 & 838 & 1515 & 698 & 2213 & 152 \\
1970 & 520 & 1085 & 1605 & 796 & 2401 & 205 \\
1980 & 424 & 1024 & 1448 & 812 & 2260 & 223 \\
\hline$\Delta 1950-80$ & -253 & 186 & -67 & 114 & 47 & 71 \\
$\% \Delta 50-80$ & $-37 \%$ & $22 \%$ & $-4 \%$ & $16 \%$ & $2 \%$ & $47 \%$ \\
\hline$\Delta 1970-80$ & -96 & -61 & -157 & 16 & -141 & 18 \\
$\% \Delta 1970-80$ & $-18 \%$ & $-6 \%$ & $-10 \%$ & $2 \%$ & $-6 \%$ & $9 \%$ \\
\hline
\end{tabular}

Source: U.S. Census of Population

shifting circuits from production to circulation made good sense and probably could make good money.

Of course, to such minds, the decline of Pittsburgh's manufacturing base was due to external conditions not of their own making while the shift to circulation, the Renaissance, was their gift to Pittsburgh and its citizens. They would not agree that the same process of accumulation which gave Pittsburgh a Renaissance also brought the decline in production. According to them, increased accumulation is always in the interests of the working class, and in this particular instance, Pittsburghers were especially fortunate to have such a benevolent intervention on their behalf. To state the obvious; the modern Pittsburgh working class had no more say or determination in the new form of accumulation than had their parents and grandparents from Europe and Africa in the decisions of the original form of capital accumulation in Pittsburgh. And the benefits and costs wouldn't be all that different either.

In trying to follow the accumulation process in Pittsburgh during this period, then, we must keep in mind three intertwined forces, (1) the decline of the region within; (2) an expanding national economy based on the internationalization of capital; and with (3) the active intervention of the ruling class to reshape the economic structure.

\section{POPULATION AND THE LABOR FORCE}

Table 18 shows what happened to total population in the region between 1950 and 1980 . The region as a whole barely maintained its population, with an increase of only $2 \%$ compared to a $47 \%$ increase in the national population. The dispersion of people continued and the City of Pittsburgh lost over a third of its inhabitants. The remainder of Allegheny County and the other counties in the SMSA showed weak growth. 
TABLE 19

Components of Population Change

in the Pittsburgh SMSA, 1920-80

(in thousand persons)

\begin{tabular}{cccc}
\hline Pittsburgh SMSA & $\begin{array}{c}\text { Net Change } \\
\text { in Population }\end{array}$ & $\begin{array}{c}\text { Natural } \\
\text { increase }\end{array}$ & $\begin{array}{c}\text { Net } \\
\text { Migration }\end{array}$ \\
\hline $1920-30$ & 263.3 & 290.4 & -27.2 \\
$1930-40$ & 59.3 & 130.8 & -71.6 \\
$1940-50$ & 130.8 & 225.0 & -94.3 \\
$1950-1960$ & 192.2 & 295.1 & -103.0 \\
$1960-1970$ & -4.2 & 163.0 & -167.2 \\
$1970-1980$ & -141.0 & $33.0^{\mathrm{e}}$ & $-174.0^{\mathrm{e}}$ \\
\hline
\end{tabular}

Data does not necessarily add exactly to totals because of rounding.

$\mathrm{e}=$ estimate.

Source: Lowry, p. 42; Pennsylvania Statistical Abstract 1980, p. 27; Current Population Report Series p. $26,1978$.

However, when we examine the most recent period the situation is actually more serious, for in the last two decades the entire regional population has been declining. This decline has been especially precipitous in the last ten years with the city losing nearly 100,000 people and the region as a whole 140,000 . Further, even the suburban ring did not fare well with the first ring, the rest of Allegheny County showing a $6 \%$ decline and the farther ring a mere 16,000 or $2 \%$ increase. Looking at the components of population change, natural increase and net migration in Table 19, we see that the problem is of long duration, 60 years, and growing. In the most recent decade people were leaving the Pittsburgh region at a new outflow of 335 every week. It is not unreasonable to assume that the migrants are for the most part younger, better educated workers and their families. This assumption is consistent with the extremely low estimated net natural increase of only 33,000 for the past decade. This will of course have a negative effect on the capacities and skills of the labor force. It may be, however unfortunate, that Pittsburgh's major export is labor.

By 1970 the foreign born population was not a significant factor in the general population, totaling only 107,000 or $4 \%$. The strong tradition of ethnic diversity in Pittsburgh which can still be observed today is the result of past rather than current historical developments.

Pittsburgh's black population grew moderately from about $135,000(6 \%)$ to $185,000(8 \%)$. The high black inmigration to northern metropolitan areas such as Washington, Detroit, New York, and Philadelphia which followed World War II and lasted for 15 years did not affect Pittsburgh because labor market conditions were not attractive to new workers. The modest increase in black population is due to natural increase and the fact that black outmigra- 
TABLE 20

Population and Labor Force Data for the Pittsburgh SMSA

1950, 1960, 1970, and 1980

Actual and Expected

(Thousands of people)

\begin{tabular}{|c|c|c|c|c|c|c|c|}
\hline Year & 1950 & 1960 & 1960 & $19 \hat{70}$ & 1970 & $1 \hat{980}$ & 1980 \\
\hline Population & 2213 & $25 \hat{08}$ & 2405 & $25 \hat{6} 8$ & 2401 & $2 \hat{434}$ & 2260 \\
\hline Labor Force & 930 & $10 \hat{5} 3$ & 952 & $10 \hat{2} 7$ & 985 & $9 \hat{98}$ & 1010 \\
\hline L.F. Participation Rate & .42 &.$\hat{4} 2$ & .40 &.$\hat{4} 0$ & .41 & $\hat{4} 1$ & .45 \\
\hline Employment & 866 & 868 & 868 & 947 & 947 & 939 & 939 \\
\hline Unemployment & 64 & $1 \hat{8} 5$ & 84 & $\hat{8} 0$ & 36 & $\hat{5} 9$ & 75 \\
\hline Unemployment Rate & $6.9 \%$ & $1 \hat{7.6}$ & 8.8 & $\hat{7.8}$ & 3.6 & $\hat{5.9}$ & 7.4 \\
\hline
\end{tabular}

Source: Pennsylvania Abstract, Selected Years.

$\wedge$ = Expected.

tion rates are lower than white. The black population is heavily concentrated in the city of Pittsburgh where they constitute perhaps one-quarter of the population of the city today. Because of these demographic trends the black population in Pittsburgh is more stable and not as socially volatile as in cities where the ranks of young unemployed blacks are swelled by migration. Still all the features of U.S. racism operate with respect to the black population in Pittsburgh. Labor markets, housing, income levels, crime, education, etc., all function to the disadvantage of the black community and, as elsewhere they contribute disproportionately to the reserve army of labor and the low wage employment sector.

The development of the labor force, employment, and unemployment in the Pittsburgh region from 1950 to 1980 reflects two aspects of the accumulation process during this time. First, the declining accumulation situation in the region required adjustments in employment and the labor force. In general, regional unemployment rates were significantly higher than the national rates from 1950 to 1965 . The U.S. economy was growing throughout this period but the region was not, except for the Korean War years. From 1958 to 1963 regional unemployment averaged over $9.5 \%$. The process of regional adjustment was more or less complete by 1965 and, with the impetus of the Vietnam War, the regional economy showed less unemployment than the nation for several years. However, beginning in the late 60's or early 70's the national economy itself began to show weakening accumulation, and this crisis with short term variations has lasted until the present. Thus, just as the local economy was stabilizing, it became subject to the general nationwide crisis in accumulation. As a result the last decade began with regional unemployment rates at somewhat less than national rates and ended with higher local rates than the United States. 
How does a regional working class adjust to the restructuring imposed on it by the ebb and flow of the accumulation process itself when natural increase, migration, and the labor force participation rate determine the level of unemployment? Table 20 shows the actual data for the region as well as "expected" results at the end of each decade. These are based on the following assumptions: employment is determined by the accumulation process and is the actual figure; the expected population is the previous population plus natural increase; the expected labor force equals the expected population times the previous labor force participation rate.

This will generate an expected level and rate of employment. By comparing these expected results with the actual data we can see at an aggregate level what mechanism "solved" or "created" the unemployment problem, based on the assumption that the accumulation process is the first and primary force. By 1960 unemployment in the region would have been a staggering $17.6 \%$ but, because of the net outmigration and a small reduction in the labor force participation rate, it measured only $8.8 \%$. By 1970 the expected rate would have been $7.8 \%$ but, again, the very substantial outmigration coupled with a stronger accumulation process reflected in higher levels of employment brought the rate down to $3.6 \%$. If the conditions of 1970 plus the natural increase in population prevailed in 1980 the expected unemployment rate would have been $5.9 \%$. However, the general weakening of accumulation and the reduction in real wages through inflation encouraged more people to enter the labor force. This response occurred both regionally and nationally. At the regional level the increase in labor force participation overcame the even larger outmigration of the 70's and resulted in an actual unemployment rate in 1980 of $7.4 \%$, slightly higher than the national average.

The employment outlook for the region is uncertain. Much depends on the national economy. It is unlikely that there will be many new jobs created in the region. On the other hand, natural increase has slowed to a trickle, and outmigration especially of the more educated, younger workers will probably continue. Thus unemployment may not rise or may even fall. However, if inflation continues to increase, the labor force participation rate measured unemployment could remain at a high level.

Pittsburgh is often cited as a prime example of a declining city in the declining Northeast region. While this is correct each decline is unique or particular and Pittsburgh's decline started well before many of the other cities. Its "adjustment" primarily through the migration process shows clearly that labor is just another form of capital to be utilized or not as the accumulation process dictates and, further, that capital accumulation cannot afford to consider "community" or "sense of place." Profitability may create a community or destroy it, and Pittsburgh has seen both developments. There is a dark side to the "free mobility of labor."

When we examine the industrial employment distribution at a more disaggregated level we see other changes and adjustments. As Table 21 reveals, by 
TABLE 21

Nonagricultural Wage and Salary Workers in the U.S. and Pittsburgh SMSA in 1952 and 1979

\begin{tabular}{|c|c|c|c|c|c|}
\hline \multicolumn{6}{|c|}{1952} \\
\hline & \multicolumn{2}{|l|}{ Pgh $(000)$} & \multicolumn{2}{|c|}{ U.S. $(000,000,000)$} & \multirow{2}{*}{$\frac{\text { Pgh } \%}{\text { US \% }}$} \\
\hline Total & 822.6 & $\%$ & 48.8 & $\%$ & \\
\hline MANU & 343.6 & 41.8 & 16.6 & 34.1 & 123 \\
\hline MINING & 26.4 & 3.2 & .9 & 1.8 & 178 \\
\hline CONST & 42.7 & 5.2 & 2.7 & 5.5 & 96 \\
\hline TCPU & 76.3 & 9.3 & 4.2 & 8.6 & 108 \\
\hline TRADE & 157.9 & 19.2 & 10.0 & 20.5 & 94 \\
\hline FIRE & 27.3 & 3.3 & 2.0 & 4.1 & 80 \\
\hline SERVICES & 82.5 & 10.0 & 5.7 & 11.7 & 85 \\
\hline GOVT & 65.9 & 8.0 & 6.6 & 13.6 & 59 \\
\hline \multicolumn{6}{|c|}{1979} \\
\hline Total & 960.6 & $\%$ & 89.5 & $\%$ & \\
\hline MANU & 254.9 & 26.5 & 21.0 & 23.5 & 113 \\
\hline MINING & 11.2 & 1.2 & .9 & 1.0 & 120 \\
\hline CONST & 49.0 & 5.1 & 4.6 & 5.2 & 98 \\
\hline TCPU & 63.0 & 6.6 & 5.1 & 5.7 & 116 \\
\hline TRADE & 206.9 & 21.5 & 20.1 & 22.5 & 96 \\
\hline FIRE & 44.8 & 4.7 & 5.0 & 5.6 & 84 \\
\hline SERVICES & 206.6 & 21.5 & 17.0 & 19.1 & 113 \\
\hline GOVT & 124.2 & 12.9 & 15.6 & 17.5 & 74 \\
\hline
\end{tabular}

Source: Employment and Earnings, U.S. Bureau of Labor Statistics.

1979 the regional industrial structure is not nearly as different from the national distribution as was the case in 1952. Pittsburgh now shows only a slight specialization in manufacturing, and thus its historical uniqueness is disappearing. As capitalists have reshaped the accumulation role of Pittsburgh from production to circulation, the predominance of manufacturing activity is reduced. Table 21 also shows the overall weak growth of the Pittsburgh labor market, up only $17 \%$ in 27 years when compared with the U.S. which increased by $83 \%$. Examining the coefficients of specialization in the last column of Table 21 indicates the variation of the Pittsburgh economy from the national average. In the major employment categories of manufacturing, trade, and services the deviations are not large. In the government category, a lower proportion of federal government jobs probably accounts for the region's low coefficient of specialization.

When we examine the employment-occupational distributions for Pittsburgh and the U.S. as shown in Table 22, a similar picture develops. Pittsburgh is more like the U.S. at the end of the period than it was in the 
TABLE 22

Occupational Distribution for the U.S. and Pittsburgh SMSA

\begin{tabular}{|c|c|c|c|}
\hline & $\begin{array}{l}1980 \\
\text { U.S. }\end{array}$ & $\begin{array}{c}1978 \\
\text { Pgh SMSA }\end{array}$ & $\operatorname{Pgh} \%$ \\
\hline Total No. & 97.3 million & 955,000 & U.S. \% \\
\hline \multicolumn{4}{|l|}{ Percentage Distribution: } \\
\hline White Collar & $52.2 \%$ & $50.4 \%$ & 97 \\
\hline $\begin{array}{l}\text { Professional and } \\
\text { Technical }\end{array}$ & 16.1 & 17.3 & 107 \\
\hline Manager & 11.2 & 8.7 & 78 \\
\hline Sales & 6.3 & 7.5 & 119 \\
\hline Clerical & 18.6 & 16.8 & 90 \\
\hline Blue Collar & 31.7 & 34.6 & $\underline{109}$ \\
\hline Craftsmen & 12.9 & 15.2 & $\overline{118}$ \\
\hline Operatives & 10.6 & 10.2 & 96 \\
\hline Trans. Equipment & 3.6 & 3.1 & 86 \\
\hline Laborers & 4.6 & 6.1 & 133 \\
\hline Service Workers & 13.3 & 14.0 & $\underline{105}$ \\
\hline Farm Manager & 1.5 & & - \\
\hline Farm Workers & 1.3 & 1.0 & 77 \\
\hline
\end{tabular}

Source: Geographic Profile of Employment and Unemployment by States 1978, Metropolitan Areas 1977-1978. Bureau of Labor Statistics Report 571.

beginning. As with manufacturing employment, Pittsburgh is still slightly over-represented in the blue collar occupations of craftmen and laborers. But Pittsburgh has been following the national trend of an increasing proportion of white collar workers which is consistent with the shifting emphasis in accumulation. The de-emphasis of industrial production and the focusing on the creation of a corporate managerial headquarters center in Pittsburgh implies the shift from blue to white collar. It also implies a shift in the Marxian categories from productive to unproductive labor as the region is now more concerned with the realization and distribution of surplus value rather than the creation of that value. Of course this is not an either/or issue and certainly manufacturing activity and blue collar occupations are still significant in the local economy. However, the picture of Pittsburgh as a blue collar town is probably overdrawn, for of the thirty largest metropolitan areas in the country eight have an equal or greater percentage of their employment in blue collar occupations. Given the generally bleak prospects for manufacturing activities in the region, we can expect a continued growth in the white collar and service sectors. 
TABLE 23

Manufacturing in the Pittsburgh SMSA

1947-1977

\begin{tabular}{c|c|c|c|c|c|c|c}
\hline Year & $\begin{array}{c}\text { Expenses } \\
(000,000)\end{array}$ & $\begin{array}{c}\text { Capital }^{1} \\
(000,000)\end{array}$ & $\begin{array}{c}\text { Production } \\
\text { Workers } \\
000\end{array}$ & $\begin{array}{c}\text { Wages } \\
000,000\end{array}$ & $\begin{array}{c}\text { Total } \\
\text { Emp. } \\
000\end{array}$ & $\begin{array}{c}\text { Total } \\
\text { Payroll } \\
(000,000)\end{array}$ & $\begin{array}{c}\text { Value } \\
\text { Added } \\
(000,000)\end{array}$ \\
\hline 1947 & $2,169^{\mathrm{e}}$ & $1,857^{\mathrm{e}}$ & 284 & 807 & 338 & 1,023 & 1,704 \\
1958 & 3,337 & 3,007 & 203 & 1,057 & 306 & 1,798 & 2,622 \\
1967 & 4,442 & 4,283 & 197 & 1,350 & 300 & 2,383 & 3,838 \\
1972 & 5,392 & 5,916 & 166 & 1,577 & 262 & 2,838 & 4,157 \\
1977 & 9,145 & 8,963 & 154 & 2,312 & 240 & 4,038 & 6,478 \\
\hline
\end{tabular}

Source: U.S. Census of Manufactures.

${ }^{1}$ Capital 1958-1977 Fogerty, Michael S. and Garofalo, Gasper, "The Urban Capital Stock and the Life Cycle of Cities," unpublished manuscript 1981.

$\mathrm{e}=$ estimated.

\section{MANUFACTURING IN THE PITTSBURGH ECONOMY}

Manufacturing, though losing ground, is still the major economic activity in the Pittsburgh region. Although this may not continue to be the case for the next 30 years, manufacturing has still been important and central during recent decades. As Table 23 shows, output has grown but the number of production workers has fallen drastically. This results from two processes, one regional and one national. At the national level the process of production has been significantly restructured since World War II by increasing the organic composition of capital, that is, the machines and raw materials that each production worker has to work with. This increased productivity of labor has in part been labor's undoing in that it reduces the number of jobs, at least relatively, in the productive sector. Thus even at the national level the number of production workers in manufacturing has remained stable or declined in the last decade. Additional pressure was placed on the Pittsburgh economy as one which was losing its profitability. The restructuring here, then, involved both a substitution of constant for variable capital and a reduction in the total productive apparatus. Pittsburgh's relative decline in production worker employment is revealed in its share of the national total. In 1947 the region contained $2.38 \%$ of all manufacturing production workers whereas by 1977 the percentage was 1.12 , only slightly above Pittsburgh's share of population.

An examination of relative regional value added and productivity can also show how the region fared in this period. In Table 24, we see that value added grew over three times as fast in the nation as in the region. Again, relatively, the region is losing ground. However, in looking at two measures of labor productivity we see that Pittsburgh was comparable to the nation. In general, then, the restructuring, i.e., the shrinking and substitution, when viewed in terms of 
TABLE 24

Value Added in Manufacturing in the Pittsburgh

SMSA and U.S. (1967 \$) and Average Annual Rates of Growth

\begin{tabular}{l|c|c|c|c|c|c}
\hline \multicolumn{5}{c|}{ Pittsburgh } & \multicolumn{3}{c}{ U.S. } \\
\hline & VA & $\frac{\text { VA }}{\mathrm{PW}}$ & $\frac{\mathrm{VA}}{\mathrm{TE}}$ & $\begin{array}{c}\text { VA } \\
(\text { Billion } \$)\end{array}$ & $\frac{\mathrm{VA}}{\mathrm{PW}}$ & $\frac{\mathrm{VA}}{\mathrm{TE}}$ \\
& $(000,000)$ & & & & & \\
\hline 1947 & $\$ 2,543$ & $\$ 8,950$ & $\$ 7,25$ & $\$ 110.9$ & $\$ 9,305$ & $\$ 7,750$ \\
1977 & 3,560 & 23,130 & 14,850 & 322.0 & 23,360 & 16,320 \\
Average Annual Growth & $1.1 \%$ & $3.2 \%$ & $2.3 \%$ & $3.6 \%$ & $3.1 \%$ & $2.5 \%$ \\
\hline
\end{tabular}

Source: Census of Manufactures.

productivity has been successful. However, the value added per total employee is $10 \%$ higher at the national level and this is reflected in the region's lower profitability as will be discussed below.

Within the Pittsburgh manufacturing economy three types of possible restructuring are worth examining: the shift in type of worker, the shift in the spacial distribution, and changes in the industrial mix. Table 25 shows the percentage distribution and average salary for three different kinds of manufacturing workers. As can be seen, between 1954 and 1977 there was a substantial shift in the composition of manufacturing employment in the Pittsburgh region from production to nonproduction workers and particularly to central office jobs. The relative salaries did not change much; however, care should be taken in interpreting the high central office salaries. These averages combine executives, professionals, and technicians with clerical and low paid service employees. Therefore, without taking into account the distribution of central office employment, one cannot conclude that the region's workers are better off with a shift away from production and toward central office (CBD) employment. In fact most of the displaced production workers are not qualified for central office employment.

TABLE 25

Production, Non-Production, and Central Office Employment in the Pittsburgh SMSA 1954 and 1977

\begin{tabular}{c|cc|rc|rc}
\hline & \multicolumn{2}{|c|}{$\begin{array}{c}\text { Production } \\
\text { Workers }\end{array}$} & \multicolumn{2}{c|}{$\begin{array}{c}\text { Non-Production } \\
\text { Workers at Plant }\end{array}$} & \multicolumn{2}{c}{$\begin{array}{c}\text { Central Office } \\
\text { Employment }\end{array}$} \\
\hline Year & $\%$ & Ave. Wage & $\%$ & Ave. Salary & $\%$ & Ave. Salary \\
\hline 1954 & 72 & $\$ 4,150$ & 19 & $\$ 5,780$ & 9 & $\$ 6,850$ \\
1977 & 64 & 15,020 & 22 & 18,550 & 14 & 22,640 \\
\hline
\end{tabular}

Source: Census of Manufacturers. 
TABLE 26

Spacial Distribution of Total Employment in Manufacturing in the Pittsburgh SMSA 1947-1977

\begin{tabular}{|c|c|c|c|c|c|c|c|c|}
\hline \multirow[b]{2}{*}{ Year } & \multicolumn{2}{|c|}{ City of Pgh } & \multicolumn{2}{|c|}{$\begin{array}{c}\text { Rest of } \\
\text { Allegheny }\end{array}$} & \multirow{2}{*}{$\begin{array}{c}\text { Allegheny } \\
\text { County } \\
\text { No. }\end{array}$} & \multicolumn{2}{|c|}{$\begin{array}{l}\text { Rest of } \\
\text { SMSA }\end{array}$} & \multirow{2}{*}{$\begin{array}{c}\text { SMSA } \\
\text { No. }\end{array}$} \\
\hline & No. & $\%$ & No. & $\%$ & & No. & $\%$ & \\
\hline 1947 & 81.0 & 24 & 141.5 & 42 & 222.5 & 115.4 & 34 & 337.9 \\
\hline 1977 & 55.3 & 23 & 95.0 & 40 & 150.3 & 89.4 & 37 & 239.7 \\
\hline
\end{tabular}

Source: Census of Manufacturing.

The changes in the spacial distribution of manufacturing employment show modest but not significant shifts. The most important fact is the net loss of 100,000 manufacturing jobs in the region, with a loss of $130,000(46 \%)$ production worker jobs and a gain of 30,000 nonproduction jobs. The overall spacial distribution shows little tendency to spread or disperse, thus running counter to the general national tendency for manufacturing jobs to leave the central city. Two reasons for this regional pattern are: first, Pittsburgh did not grow and some of the dispersal of manufacturing within metropolitan areas in this period was attributable to new firms or plants locating outside the central cities. Second, the nature of Pittsburgh manufacturing activity, with its heavy emphasis on steel production, implied early dispersion along the rivers; several plants constructed at the beginning of the century were 20 miles or more from the Point or CBD.

The industrial mix in Pittsburgh has shifted somewhat in this period as Table 27 indicates. Primary and fabricated metals still dominate the mix accounting for almost half of the manufacturing employment and showing a level 3.43 times as great as the national economy. The "metals group" which adds machinery, electrical machinery, and transportation equipment accounts for nearly two-thirds of all regional manufacturing activity. However, both of these shares are significantly smaller than the 1954 concentrations. We can probably expect this despecialization to continue as steel capital, seeking more profitable locations, bypasses Pittsburgh and directs the decline of the local steel industry.

\section{STEEL IN PITTSBURGH}

The steel industry in Pittsburgh has been both the cause and the effect of the region's relative economic decline. Nationally the steel industry has been relatively declining in the last three decades. Therefore, Pittsburgh, being specialized in steel, would reflect this national trend to a greater degree. However, in addition, Pittsburgh's comparative advantage in steel production has continued to erode. The problems are reflected in the data in Table 28. In the 30 years from 1947 to 1977 real value added produced in steel increased 
TABLE 27

Industrial Mix for Selected Industries in Pittsburgh SMSA 1954 and 1977 and in the US 1977

\begin{tabular}{|c|c|c|c|c|c|c|}
\hline \multirow[b]{3}{*}{$\begin{array}{l}\text { Selected } \\
\text { Industries }\end{array}$} & \multicolumn{4}{|c|}{ Pittsburgh } & \multirow{2}{*}{\multicolumn{2}{|c|}{$\begin{array}{l}\text { U.S. } \\
1977\end{array}$}} \\
\hline & \multicolumn{2}{|c|}{1954} & \multicolumn{2}{|c|}{1977} & & \\
\hline & \begin{tabular}{|c|} 
No. emp \\
$(000)$
\end{tabular} & $\%$ & $\begin{array}{c}\text { No. emp } \\
(000)\end{array}$ & $\%$ & $\begin{array}{c}\text { No. emp } \\
(000,000)\end{array}$ & $\%$ \\
\hline All Manufacturing & 303.4 & 90.9 & 239.7 & 77.3 & 19.5 & 58.4 \\
\hline Food & 21.6 & 7.1 & 9.3 & 3.9 & 1.5 & 7.7 \\
\hline Printing & 9.0 & 3.0 & 8.9 & 3.7 & 1.1 & 5.6 \\
\hline Stone, Clay, Glass & 20.3 & 6.7 & 13.1 & 5.5 & .6 & 3.1 \\
\hline Primary Metals & 134.5 & 44.3 & 89.4 & 37.3 & 1.1 & 5.6 \\
\hline Fabricated Metals & 30.4 & 10.0 & 19.9 & 8.3 & 1.5 & 7.7 \\
\hline Machinery & 20.8 & 6.9 & 23.8 & 9.9 & 2.1 & 10.8 \\
\hline Electrical & 28.1 & 9.3 & 15.3 & 6.4 & 1.7 & 8.7 \\
\hline Trans. Equipment & 11.0 & 3.6 & 5.5 & 2.3 & 1.8 & 9.2 \\
\hline "Metals" Group \% & \multirow{2}{*}{\multicolumn{2}{|c|}{74.1}} & \multirow{2}{*}{\multicolumn{2}{|c|}{$\begin{array}{r}64.2 \\
153.0\end{array}$}} & \multirow{2}{*}{\multicolumn{2}{|c|}{42.0}} \\
\hline Specialization Index & & & & & & \\
\hline Prim. \& Fab. Metals \% & \multirow{2}{*}{\multicolumn{2}{|c|}{54.3}} & & 45.6 & \multirow{2}{*}{\multicolumn{2}{|c|}{13.3}} \\
\hline Spec. Index & & & & 343.0 & & \\
\hline
\end{tabular}

Source: Census of Manufacturers.

$78 \%$ in the U.S. but only $13 \%$ in Pittsburgh. The average annual rates of growth respectively were $1.9 \%$ and $.4 \%$. This slower regional growth resulted in a reduction of Pittsburgh's share from 21\% in 1947 to $13 \%$ in 1977. From 1954 to 1977 Pittsburgh lost over 27,000 jobs in basic steel, and over 25,000 of those were production workers. The restructuring of steel in Pittsburgh followed the national tendency of raising the organic composition of capital, but the effect was sharper locally. As a result the regional rate of growth in productivity of $2.0 \%$, roughly measured by the ratio of value added per worker, was equal to the national rate. Thus we can conclude that in this period Pittsburgh maintained its relative efficiency but only by growing at a slower rate.

The major technological changes were only partially adopted in the Pittsburgh steel industry. The basic oxygen furnace which has become the dominant steel making process since it was developed in Austria in 1953 was introduced only on a limited basis. Of the new BOF capacity built in the U.S. between 1954 and 1977, 11\% was constructed in Pittsburgh (Hogan, pp. 1546-47). With regard to the other major technological advance, continuous casting, Pittsburgh had roughly 7\% of the national capacity by 1971 (Hogan, pp. 1567-68). At the level of new capital expenditures in general, the Pittsburgh steel industry's share in 1977 was only $9 \%$ below its 13\% share of the 
TABLE 28

Average Annual Rates of Growth in Value Added and Valued Added/Total

Employment in Steel in the Pittsburgh SMSA and the U.S. 1947-1977

\begin{tabular}{lcccccr}
\hline \multicolumn{3}{c}{ Pittsburgh } & \multicolumn{3}{c}{ U.S. } \\
\hline & $\begin{array}{c}\text { Value Added } \\
(000,000)\end{array}$ & $\begin{array}{c}\text { VA 1967 \$ } \\
(000,000)\end{array}$ & $\begin{array}{l}\text { V.A. } \\
\text { T.E. }\end{array}$ & $\begin{array}{c}\text { Value Added } \\
(000,000)\end{array}$ & $\begin{array}{c}\text { VA 1967 \$ } \\
(000,000)\end{array}$ & $\frac{\text { V.A. }}{\text { T.E. }}$ \\
\hline 1947 & 567.7 & 1,034 & 8,682 & 2,657 & 4,840 & 8,869 \\
1977 & $2,443.0$ & 1,169 & 15,905 & 18,048 & 8,635 & 16,292 \\
\hline $\begin{array}{l}\text { Annual } \\
\text { Growth }\end{array}$ & $5.0 \%$ & $.4 \%$ & $2.0 \%$ & $6.6 \%$ & $1.9 \%$ & $2.0 \%$ \\
\begin{tabular}{l} 
Rate \\
\hline
\end{tabular} & & & & & & \\
\hline
\end{tabular}

Source: Census of Manufactures.

market. Other developments in steel production and the behavior of steel firms also do not look favorable for Pittsburgh, such as the development of the "mini mill," a relatively small scale operation located close to market. In addition, large steel firms responding to low profits are diversifying in terms of products, e.g., cement, chemicals, and geographically, e.g., Italy, Spain, India, Indonesia, Venezuela, and South Africa (Hogan, pp. 1665-68). Finally, to rationalize accumulation, some firms are closing old mills or parts thereof, e.g., at the beginning of 1981, 1000 workers at the J\&L Pittsburgh Works were permanently laid off as the company tried to close out its unprofitable operations. All of these changes are experienced within the context of the national steel industry's weakened competitive position vis-a-vis foreign producers. Pittsburgh, once the center of world steel production, faces an unpromising future for a shrinking steel industry.

The history of labor in steel takes on a new character in this period. Since unionization on a national scale has been achieved, the struggles between capital and labor were no longer regional and had a regularized bureaucratic form. Between 1945 and 1959 there were five major strikes in steel in a context of eleven collective bargaining agreements (Hogan, pp. 1611-41). These strikes lasted between one and two months except for the 1959 strike of 116 days. Although these strikes were large, usually involving half a million workers, they have little of the character of class struggle. Or put differently, they represent the class struggle in a bureaucratized form. The timing of the strikes, the rules governing them, the decisions to delay them are all determined by the bureaucracies representing labor and capital with assistance and intervention by the state. In the present mode, instead of sending in troops, the state sends in arbitrators and mediators in recognition of the fact that the modern steel workers' union does not represent a threat to capital or the social order but is itself one of the mainstays of that social order. 
There have been no nationwide strikes since 1959, and the tendencies to bureaucratic solutions were enhanced with the so called "productivity bargains" of the 1960's in which workers agreed to restrict wage increases to the level of productivity gains. The culmination of this trend was the Experimental Negotiating Agreement of 1975 in which the workers agreed not to strike and, if no settlement could be reached, the differences would be submitted to binding arbitration. The present situation of labor in steel is uncertain. Wages are comparatively high, but jobs are shrinking. The steelworkers for the time being, those who remain employed that is, have had their lot thrown in with that of the steel capitalists. This lot, given foreign competition and limited profitability in steel, does not look good, and steelworkers will probably have to make some hard choices within the next decade to either float along with steel capital and see their numbers shrink and the younger workers disappear or to struggle against the "rationalizations" in the accumulation process as their ancestors did before them.

\section{MARXIAN VALUE ANALYSIS 1947-1977}

Using data primarily from the U.S. Census of Manufactures, we can identify the main categories of value and utilize them in a comparative economic analysis of the region. Because of some conceptual modifications it is useful to define the value categories again.

$$
\begin{aligned}
\mathrm{C} & =\text { capital stock: fixed plant and equipment } \\
\mathrm{c}_{\mathrm{d}} & =\text { depreciation (flow) } \\
\mathrm{c}_{\mathrm{rm}} & =\text { non payroll expenses } \\
\mathrm{c}_{\mathrm{u}} & =\text { payroll of non-production workers } \\
\mathrm{c} & =\mathrm{c}_{\mathrm{d}}+\mathrm{c}_{\mathrm{rm}}+\mathrm{c}_{\mathrm{u}}=\text { constant capital (flow) } \\
\mathrm{V} & =\text { payroll of production workers: variable capital } \\
\mathrm{S} & =\text { value added }=\left(\mathrm{V}+\mathrm{c}_{\mathrm{r}}+\mathrm{c}_{\mathrm{d}}\right) \text { : surplus value } \\
\mathrm{TV} & =\mathrm{c}+\mathrm{V}+\mathrm{S} \text { : total value } \\
\mathrm{q} & =\frac{\mathrm{C}+\mathrm{c}_{\mathrm{rm}}+\mathrm{c}_{\mathrm{u}}}{\mathrm{V}}: \text { organic composition of capital } \\
\mathrm{p} & =\frac{\mathrm{S}}{\mathrm{C}+\mathrm{c}_{\mathrm{rm}}+\mathrm{c}_{\mathrm{u}}+\mathrm{V}} \text { : rate of profit }
\end{aligned}
$$

There are two aspects of the definitions which should be noted. First is the distinction between capital stock $(C)$ and the flow $\left(c_{d}\right)$. In calculating the organic composition of capital and the rate profit, the stock of capital is used coupled with other expenses $\left(c_{r m}+c_{u}\right) m$ and this complicates the simpler formula given by Marx. Second, the payroll has been divided into that of productive and unproductive labor, using as a rough guide wages of production workers as the measure of productive labor $(\mathrm{V})$. Unproductive labor which, according to Marx, does not produce any surplus value has been assigned to constant capital as $\mathrm{c}_{\mathrm{u}}$. Thus it is treated as an expense born by capital, but 
TABLE 29

Marxian Values in Manufacturing for the U.S. and Pittsburgh SMSA 1947-1977

\begin{tabular}{|c|c|c|c|c|c|c|c|c|c|c|}
\hline Year & $\mathrm{C}$ & $c_{d}$ & $c_{\mathrm{rm}}$ & $c_{u}$ & $\mathrm{c}$ & V & $\mathrm{S}$ & TV & $\mathrm{q}=\frac{\mathrm{C}+\mathrm{c}_{\mathrm{rm}}+\mathrm{c}_{\mathrm{u}}}{\mathrm{V}}$ & $\mathrm{p}=\frac{\mathrm{S}}{\mathrm{C}+\mathrm{c}_{\mathrm{rm}}+\mathrm{c}_{\mathrm{u}}+\mathrm{V}}$ \\
\hline \multicolumn{11}{|c|}{ U.S. (Billions of Dollars) } \\
\hline 1947 & 30.4 & 3 & 112 & 9 & 124 & 30 & 32 & 186 & 5.0 & .18 \\
\hline 1958 & 70.9 & 8.8 & 185 & 24 & 218 & 50 & 59 & 327 & 5.6 & .18 \\
\hline 1967 & 102.4 & 13.6 & 299 & 42 & 355 & 81 & 125 & 561 & 5.5 & .24 \\
\hline 1972 & 190 & 20.7 & 407 & 69 & 497 & 105 & 159 & 761 & 6.3 & .21 \\
\hline 1977 & 311 & 35.9 & 783 & 109 & 928 & 157 & 284 & 1369 & 7.7 & .21 \\
\hline \multicolumn{11}{|c|}{ Pittsburgh (Millions of Dollars) } \\
\hline 1947 & 1857 & 83 & 2169 & 217 & 2469 & 807 & 597 & 3873 & 5.3 & .12 \\
\hline 1958 & 3007 & 139 & 3337 & 741 & 4217 & 1057 & 685 & 5959 & 6.7 & .08 \\
\hline 1967 & 4283 & 183 & 4442 & 1033 & 5658 & 1350 & 1272 & 8280 & 7.2 & .11 \\
\hline 1972 & 5916 & 269 & 5293 & 1251 & 6823 & 1577 & 1050 & 9450 & 7.9 & .07 \\
\hline 1977 & 8963 & 444 & 9145 & 1726 & 11315 & 2312 & 1996 & 15623 & 8.6 & .09 \\
\hline
\end{tabular}

Sources: Census of Manufactures.

C (capital stock) U.S.: Statistical Abstract 1978 p. 809 and selected years.

Pittsburgh: Fogerty, Michael and Garofalo, Gasper, “The Urban Capital Stock and the Life Cycle of Cities," 1981, Unpublished manuscript. 
since it does not add value it is not part of variable capital. Given this definition it appears as a part of constant capital in the organic composition and rate of profit calculations.

The results of categorizing the data in Marxian terms for the post World War II period provide some interesting insights. First, we see that the organic composition of capital rose steadily over the entire period for both the U.S. and the region. This in part reflects the rising role of unproductive labor, which is included in constant capital, but even without this effect the organic composition is rising. In this period the substitution of machines, raw materials, and unproductive labor for variable capital, the source of surplus value, has continued. This is not surprising since, as Marx pointed out, the competition among capitalists forces a continuous revolution in the means and processes of production. The maintenance of stable social relations often requires that the technological change favor the use of more $\mathrm{C}$ than $\mathrm{V}$. Additionally, as capital devotes more and more resources and concern to the circulation process and the realization of surplus value, in contrast to its production, the relationship of constant to variable capital is bound to increase given Marx's definitions of productive and unproductive labor. A second point of interest is that the organic composition of capital is significantly higher for Pittsburgh than for the U.S. This is more consistant with the notion of Pittsburgh as a heavy industry town, but beyond that it represents the more rapid shift to non-production labor within the region. If we examine the proportion of production worker wages to total wages and salaries for Pittsburgh from 1929-47 it is about 78\%, 5\% above the U.S. level, but after the war, 1958-77, the proportion is $57 \%, 10 \%$ below the national average. Part of the restructuring of the post war Pittsburgh economy consisted of rapidly reducing the proportion of production workers in manufacturing. Perhaps this was a response to unionization.

Comparison of the regional and national profit rates is also interesting. First, one is struck by the significant difference in the levels of the profit rates with the national being more than twice the local rate. This reflects the serious accumulation problems within the Pittsburgh regional economy and raises the question of whether or not the complete regional adjustment has been achieved. An economy which is producing profits at less than half the national rate may still be in need of further radical restructuring. A second consideration is the direction of the rate of profit. While the national rate for the period examined has a slight upward trend the regional rate is at best stable at a low level or perhaps still falling. This information also supports the conclusion that further restructuring of the regional manufacturing economy is necessary before a satisfactory accumulation process can be re-established. Finally, we can ask if the results support the Marxian hypothesis of a falling rate of profit. Clearly at the national level the evidence is contrary, showing a constant or slightly rising rate of profit in the face of an increasing organic composition of capital. However, at the regional level the results could be interpreted as supportive of Marx's claim. One conjecture is that the falling rate of profit may be 
TABLE 30

Ratio of Production Workers Wages and Total Employees Wages to Value Added 1947-1977

\begin{tabular}{|c|c|c|c|c|}
\hline \multirow[b]{2}{*}{ Year } & \multicolumn{2}{|c|}{ U.S. } & \multicolumn{2}{|c|}{ PGH. } \\
\hline & $\begin{array}{l}\text { Prod. Wages } \\
\text { Value Added }\end{array}$ & $\frac{\text { Total W\&S }}{\text { Value Add. }}$ & $\frac{\text { Prod. Wages }}{\text { Value Added }}$ & $\frac{\text { Total W\&S }}{\text { Value Add. }}$ \\
\hline 1947 & .41 & .53 & .47 & .60 \\
\hline 1958 & .35 & .52 & .40 & .69 \\
\hline 1967 & .31 & .47 & .35 & .62 \\
\hline 1972 & .30 & .49 & .38 & .68 \\
\hline 1977 & .27 & .45 & .36 & .62 \\
\hline
\end{tabular}

Source: Census of Manufactures.

experienced more frequently at a regional level where there is no place or venture to run to and options are more restricted than at a national or international level where the possibilities of developing counter tendencies may be much greater.

A final look at a crude economic measure of the course of the class struggle can be had by examining the share of wages in value added. The striking thing about the data in Table 30 is the significantly higher share of wages in the Pittsburgh region when compared to the nation. One might argue that the role of physical capital in the production process is what accounts for this difference, but the higher organic composition and lower profit rate in the Pittsburgh region leads to the more direct conclusion that labor in the region gets a higher share of value added. Further, when looking at the changes over time, it is clear that the Pittsburgh workers have held their share more successfully than U.S. manufacturing labor as a whole. Additional evidence of the favored position of the Pittsburgh production worker is an average hourly wage of $\$ 7.86$ in 1977 compared to the U.S. average of $\$ 5.89$; Pittsburgh is one third higher. The average payroll in Pittsburgh is also higher, $\$ 16,860$ compared to a national figure of $\$ 13,480$; Pittsburgh is $25 \%$ higher. These higher wage shares and earnings reflect on the one hand the strength and success of the Pittsburgh working class and on the other the resolve of the capitalists to "redress this imbalance" either through cutting wages or capital flight. In an era of international capitalism, regional workers stand little chance of maintaining favorable differentials over more than the short run. Capital has internationalized the proletariat, and the Pittsburgh production worker is in competition with all the recently urbanized peasants of the third world, a competition that he or she cannot win.

\section{SUMMARY}

The Pittsburgh region conforms closely to the historical pattern of capital accumulation in the United States. Starting with pre-capitalist origins in petty 
commodity production and merchantilist activity, it developed into a regional economic center by mid 19th century. In the period of industrialization following the Civil War, competitive capitalism in Pittsburgh provided the impetus to the great accumulation of capital. Pittsburgh became a national manufacturing center for the production of surplus value. The two great classes or forces of capitalism, labor and capital, were developed in the nation and in Pittsburgh in this period. The 20th century was ushered in with the formation of the great monopoly capitalist enterprise, U.S. Steel, and a new era begins in which other great monopoly organizations develop such as Gulf Oil, Alcoa, and Westinghouse Electric. During the first half of the 20th century Pittsburgh's economy was still based on manufacturing, but it was a period of relative regional decline. Following World War II it was clear that a dramatic restructuring of the Pittsburgh economy was necessary if the region was to maintain an important role in the accumulation process. Given the new internationalization of capital and regional specializations, an attempt was made, under the direction of the Mellon interests, to shift Pittsburgh from a center producing surplus value to one managing and circulating surplus value. This accounts for the regional employment shifts from manufacturing to nonmanufacturing and from productive to unproductive labor.

Restructuring the economy to produce an international accumulation focus required a number of adjustments and developments. Manufacturing activity was reduced, consolidated and reorganized. In particular, constant capital was substituted for variable capital, and, with limited new investment, the more profitable elements were retained and the others eliminated. A "Renaissance" was undertaken to remake parts of Pittsburgh in a form more suitable for its new functions. Most affected was the CBD where old rail lines and stations and commercial districts were razed and new office buildings, hotels, arenas, parks and fountains were constructed. The face-lifting included smoke and water pollution controls, improved public and private regional transportation networks, and a general attempt to raise the level of ammenities at least in the central city. In addition, the area was expected to become a research and development center and, consequently, private and public resources were directed to higher education with the University of Pittsburgh favored from 1955-65 and Carnegie Institute adding a Mellon to its name for a reputed gift of $\$ 100$ million. These institutions were to provide, in part, the technical and professional personnel for the new accumulation.

Evidence of the internationalization of Pittsburgh capital can be seen from the fact that $35 \%$ of the total profit of five of the major Pittsburgh corporations, Gulf, U.S. Steel, Westinghouse, Alcoa, and Heinz, was the result of international operations. ${ }^{*}$ Thus a new form of dependency was created for the Pittsburgh economy. Whereas, in the past, the region's economic welfare was tied to the nation cycle of demand for steel and other commodities, today the

*Calculated from Annual Reports of these corporations. 
well being of the Pittsburgh working class is contingent on the vicissitudes of U.S. imperialism.

Once again the Pittsburgh area finds itself developing parallel to the national economy. From regional, to national, to international dependence, it reflects 200 years of U.S. economic history. The region's future is inextricably bound with the future of capital accumulation on a world scale. The contradictions in this process will be the determinants of the Pittsburgh regional economy in the rest of the 20th century.

\section{REFERENCES}

[1] FOGERTY, MICHAEL AND GAROFALO, CASPER, "The Urban Capital Stock and the Life Cycle of Cities," unpublished manuscript, 1981.

[2] HOGAN, WILlIAM T., Economic History of Iron and Steel Industry in the United States, Vols. 1-5, Lexington Books, 1971.

[3] LOWRY, IRA S., Portrait of a Region, University of Pittsburgh Press, 1963.
[4] PENNSYLVANIA BUREAU OF STATISTICS, RESEARCH AND PLANNING, Pennsylvania Statistical Abstract.

[5] U.S. BUREAU OF LABOR STATISTICS, Employment and Earnings.

[6] U.S. BUREAU OF THE CENSUS, United States Census of Manufactures, 1849-1977.

[7] U.S. BUREAU OF THE CENSUS, United States Census of Population, 1800-1970.

[8] U.S. BUREAU OF THE CENSUS, Statistical Abstract of the United States. 